\title{
DAKWAH KOMUNIKASI VISUAL
}

\author{
Nilnan Ni'mah \\ Jurusan KPI Fakultas Dakwah dan Komunikasi UIN Walisongo Semarang \\ Email : nilnanwalisongo@gmail.com
}

\begin{abstract}
$D$ a'wah is a duty of every Muslim to invite others, especially Muslims do good things and forbidding evil. In conducting missionary activities, media needed to facilitate mad'u received and understood the messages. One of the interesting media propaganda is visual communication media, which are all communications media that can be ingested by senses of sight, such as books, advertisements, banners, billboards, posters, flyers, and so on. While islamic posters is media which progressing since 2010 up to the last few years. Islamic posters must have a clear concept, and should include the source of the Qur'an and hadith or of the thinkers of Islam. Posters made up not only arbitrary, but it could be true. These posters are useful to remind Muslims especially, to always return to the path of God.
\end{abstract}

Key Words : Da'wah, Visual Media, Islamic Posters

\section{ABSTRAK}

Dakwah adalah kewajiban setiap Muslim untuk mengajak orang lain, terutama umat Islam melakukan hal-hal yang baik dan mencegah kemungkaran. Dalam melakukan kegiatan dakwah, diperlukan media atau sarana agar mad'u menerima dan memahami pesan. Salah satu media dakwah yang menarik adalah media komunikasi visual, yaitu semua media komunikasi yang dapat dicerna oleh indera penglihatan, seperti buku, iklan, spanduk, baliho, poster, selebaran, dan sebagainya. Poster Islam adalah salah satu media dakwah yang mulai berkembang sejak tahun 2010 sampai beberapa tahun terakhir. Poster Islam harus memiliki konsep yang jelas, dan harus mencakup sumber dari Al-Qur'an dan hadits atau dari para pemikir Islam. Poster dibuat tidak hanya asal-asalan, tetapi harus benar. Poster ini berguna untuk mengingatkan umat Islam khususnya, untuk selalu kembali ke jalan Allah SWT.

\section{Kata Kunci : Dakwah, Media Visual, Poster Islam}




\section{PENDAHULUAN}

DAKWAH adalah kewajiban setiap muslim untuk mengajak orang lain terutama kaum muslimin melakukan amar ma'ruf nahi munkar. Dalam sebuah hadits disebutkan bahwa "sampaikanlah walaupun hanya satu ayat". Hal ini menunjukkan bahwa sesederhana dan sekecil apapun kegiatan dan pengetahuan yang dimiliki seorang muslim harus senantiasa bernilai dakwah. Dakwah bisa dimuali dari diri sendiri, keluarga atau orang-orang terdekat, lingkungan tempat tinggal sampai pada masyarakat luas.

Dalam melakukan kegiatan dakwah, dibutuhkan media atau alat atau perantara untuk memudahkan mad'u menerima dan memahami pesan dakwah. Media dakwah yang dimaksud seperti media lisan, tulisan, visual, audio, audio visual, dan sebagainya. Media dakwah harus menyesuaikan dengan situasi dan kondisi mad'u, seperti latar belakang sosial, kultural, pendidikan, ekonomi, psikologis, dan sebagainya. Dengan media yang tepat dan sesuai, dakwah akan menjadi lebih efektif dan efisien.

Aktivitas dakwah tidak bisa dipisahkan dari aktivitas komunikasi. Secara sederhana, kegiatan dakwah adalah kegiatan berkomunikasi, proses menyampaikan pesan dari sumber pengirim pesan kepada penerima pesan melalui media dan bertujuan memberikan pengaruh atau efek pada penerima pesan. Yang membedakan dengan komunikasi adalah isi pesan dalam dakwah adalah pesan-pesan yang bersumber dari al-Qur'an dan Hadits, yang dijadikan pedoman dalam hidup umat Islam. Jadi semua aktivitas dakwah adalah aktivitas komunikasi, tetapi sebaliknya tidak semua aktivitas komunikasi adalah aktivitas dakwah.

Media dakwah yang digunakan dalam kegiatan dakwah adalah media komunikasi. Media komunikasi seperti lisan, tulisan, audio, visual, maupun audio visual digunakan dalam berdakwah. Seiring perkembangan zaman, dengan semakin canggihnya teknologi informasi dan komunikasi, dakwah pun harus menyesuaikan agar tidak tergerus zaman. Kegiatan dakwah konvensional seperti ceramah, tidak lagi hanya bisa dinikmati secara langsung lewat mimbar-mibar, tetapi juga bisa didengar di radio, dilihat di televisi atau bahkan bisa langsung di akses di internet. Begitu mudahnya manusia menggali informasi dengan kecanggihan teknologi, maka dakwahpun harus menjawab tantangan itu.

Masyarakat yang semakin cerdas dalam mengkonsumsi media (baca=media massa), menuntut dakwah pun harus lebih cerdas. Masyarakat dengan pendidikan well educated misalnya, tidak lagi mudah percaya dengan informasi yang tidak jelas sumbernya. Mereka harus melihat fakta atau bukti untuk bisa mempercayai sesuatu. Hal ini sesuai dengan istilah "seeing is believing", bahwa kita akan percaya setelah melihat sendiri kenyataannya. Orang akan lebih mempercayai apa yang mereka lihat daripada yang mereka 
dengar. Hal ini menunjukkan bahwa komunikasi visual adalah salah satu cara yang efektif untuk mengajak dan mempengaruhi orang lain untuk berpikir, bersikap dan bertindak sesuai dengan harapan pembuat pesan.

Berangkat dari stigma tersebut, dakwah pun bisa dilakukan melalui media komunikasi visual, yaitu semua media komunikasi yang bisa dicerna oleh indera penglihatan, seperti buku, iklan, spanduk, baliho, poster, selebaran, dan sebagainya. Media komunikasi visual yang sedang booming beberapa tahun terakhir ini (sejak tahun 2010 hingga enam tahun berikutnya dan masih berkembang terus) adalah poster bernuansa islami. Seperti yang disampaikan oleh Nurhadi Ismail, ketua Muslim Designer Community (MDC), salah satu komunitas desainer poster bernuansa Islam, bahwa berdakwah tidak hanya melalui mimbar-mimbar di masjid atau secara tatap muka saja, tetapi juga bisa dilakukan melalui media seni desain grafis dalam bentuk media gambar. Komunitas ini percaya bahwa kecenderungan orang untuk menangkap makna dari sebuah gambar lebih efektif daripada hanya mendengarkan ceramah saja. "Words don't mean, people mean", kata-kata tidak bermakna, tetapi manusialah yang memberi makna. Dengan kalimat-kalimat ataupun gambar yang bernuansa Islam, mereka membuat sejumlah poster untuk dipamerkan secara langsung ataupun melalui media internet.

Poster yang dibuat harus memiliki konsep yang jelas, dan harus mencantumkan sumber dari al-Qur' an dan hadits atau dari para pemikirpemikir Islam. Sehingga poster yang dibuat tidak sekedar asal-asalan, tetapi bisa dipertanggungjawabkan kebenarannya. Poster sebagai media dakwah komunikasi visual mengalami perkembangan yang semakin pesat beberapa tahun terakhir. Poster (dakwah) tidak lagi hanya ditempel atau ditampilkan secara langsung saja, tetapi mulai merambah ke media lain, seperti baju, stiker, mug, aksesoris, dan sebagainya. Semaraknya dakwah komunikasi visual ini harus terus dikembangkan untuk mengingatkan umat Islam terutama, agar selalu kembali ke jalan Allah SWT.

\section{PEMBAHASAN}

\section{Dakwah}

Secara etimologi, bahasa perkataan dakwah berasal dari kata kerja da'a yad'u da'watan, yang berarti mengajak, menyeru, memanggil, mengundang (Munawwir, 1997:406). Secara terminologi, dakwah diartikan dengan berbagai macam pengertian. Muhammad Natsir, seperti yang dikutip Rosyad Shaleh (1977:8) mendefinisikan dakwah sebagai usahausaha menyerukan dan menyampaikan pada perorangan manusia dan seluruh konsepsi Islam tentang pandangan dan tujuan hidup manusia di dunia ini, yang meliputi amar ma'ruf nahi munkar, dengan berbagai macam media dan cara yang diperbolehkan akhlak dan membimbing pengalamannya dalam perikehidupan perseorangan, perikehidupan bermasyarakat dan 
perikehidupan bernegara.

Sedangkan Wahyu Ilaihi (2006:21) dalam bukunya Manajemen Dakwah, menyebutkan dakwah adalah sebuah aktifitas atau kegiatan yang menyeru atau mengajak kepada orang lain untuk mengamalkan ajaran Islam, pelaksanaannya bisa dilakukan dengan berbagai cara atau metode. Sementara M. Arifin dalam buku Ilmu Dakwah, seperti yang dikutip oleh Aziz (2009:15-16) menyatakan bahwa dakwah merupakan suatu kegiatan ajakan dalam bentuk lisan, tulisan, tingkah laku dan sebagainya, yang dilakukan secara sadar dan terencana dalam usaha mempengaruhi orang lain secara individu maupun kelompok agar timbul dalam dirinya suatu pengertian, kesadaran, sikap, penghayatan, serta pengamalan terhadap ajaran agama.

Dasar hukum dakwah dalam QS. An-Nahl ayat 125, menyebutkan bahwa kewajiban muslim untuk menyeru atau mengajak kepada jalan Allah SWT dengan jalan yang baik dan benar, yaitu dengan hikmah, mauidhoh hasanah dan diskusi yang baik. Demikian juga dalam hadits, Rasulullah pernah bersabda: "Barangsiapa yang melihat kemungkaran, maka cegahlah dengan tanganmu, apabila belum bisa, maka cegahlah dengan mulutmu, apabila belum bisa, cegahlah dengan hatimu, dan mencegah kemungkaran dengan hati adalah pertanda selemah-lemah iman".

Aktivitas dakwah tidak bisa dilepaskan dari unsur-unsur atau komponen penunjang dakwah (Ilaihi, 2010:19), seperti da'i (pelaku dakwah), mad'u (mitra dakwah), maddah (materi dakwah), wasilah (media dakwah), thariqah (metode dakwah) dan atsar (efek dakwah). Semua unsur saling mendukung agar dakwah bisa berjalan dengan efektif dan efisien.

Salah satu unsur dakwah yang harus menyesuaikan dengan perkembangan zaman adalah unsur wasilah atau media dakwah. Menurut Asmuni Syukir (1983:163), media dakwah adalah segala sesuatu yang dapat digunakan sebagai alat untuk mencapai tujuan dakwah yang telah ditentukan. Media dakwah ini dapat berupa barang (material), orang, tempat, kondisi tertentu dan sebagainya. Dalam memilih media dakwah, seorang da'i perlu memperhatikan aspek-aspek yang terkandung didalamnya, antara lain :

1. Media yang dipilih sesuai dengan tujuan dakwah yang hendak dicapai;

2. Media yang dipilih sesuai dengan kemampuan sasaran dakwahnya;

3. Media yang dipilih sesuai dengan materi dakwahnya;

4. Pemilihan media hendaknya dilakukan dengan cara objektif, artinya pemilihan media bukan karena dasar kesukaan da'i;

5. Efektivitas dan efisiensi harus diperhatikan.

Hamzah Ya'qub seperti yang dikutip Moh Ali Azis (2004 :120121), membagi bentuk media dakwah 
sebagai berikut :

1. Media lisan, yaitu media dakwah yang menggunakan lidah dan suara, seperti ceramah, pidato, dan sebagainya.

2. Media tulisan, yaitu media dakwah yang berupa rangkaian huruf yang membentuk kata dan kalimat, seperti majalah, koran, buku, dan lain-lain.

3. Media lukisan, yaitu media dakwah yang berupa gambargambar hasil seni lukis, foto, dan lain-lain.

4. Media audio visual yaitu media dakwah yang bertujuan menyampaikan pesan dakwah melalui rangsangan penglihatan dan pendengaran, seperti televisi, sandiwara, dan sebagainya.

5. Media perbuatan atau akhlak, yaitu media penyampaian yang terwujud dalam bentuk perbuatan nyata yang dicontohkan da'i kepada mad'u.

Sedangkan dari segi pesan penyampaian dakwahnya, dibagi menjadi tiga golongan, yaitu : the spoken words (yang berbentuk ucapan, seperti tape, telepon, dsb), the printed writing (berbentuk tulisan, seperti gambar-gambar, buku, dll) dan the audio visual (berbentuk gambar hidup, seperti film, televisi, video, $\mathrm{dsb}$ ).

Jadi seorang da'i harus bisa menyesuaikan antara materi dakwah dengan media dakwah yang akan digunakan. Media dakwah yang digunakan menyesuaikan dengan kondisi mad'unya, misalnya untuk mad'u dengan latar belakang pendidikan well educated dengan mad'u yang berpendidikan rendah akan berbeda. Stimulus respons yang diberikan akan mempengaruhi efektivitas dakwah.

\section{Komunikasi Visual}

Kata atau istilah komunikasi berasal dari bahasa Latin, communicatio yang artinya berbagi atau menjadi milik bersama. Menurut kamus bahasa, komunikasi mengacu pada suatu upaya yang bertujuan untuk mencapai kebersamaan (Riswandi, 2009:1). Secara terminologis, komunikasi berarti proses penyampaian suatu pernyataan oleh seseorang kepada orang lain (Effendy, 1993 : 4).

Menurut Harold Lasswell, komunikasi pada dasarnya adalah proses yang menjelaskan siapa mengatakan apa melalui saluran apa kepada siapa dan dengan akibatapa. Jadi komunikasi adalah proses penyampaian pesan dari pengirim pesan (komunikator) kepada penerima pesan (komunikan) melalui media tertentu dan menimbulkan efek atau dampak. Edwin Emery menyampaikan bahwa komunikasi adalah seni menyampaikan pesan dari satu orang kepada yang lain. Sementara Carl I. Hovland menyatakan bahwa komunikasi adalah suatu proses dimana sesorang (komunikator) menyampaikan stimulus (biasanya dalam bentuk kata-kata) bertujuan untuk merubah tingkah laku orang lain. Everett M. Rogers mendefinisikan 
komunikasi sebagai sebuah proses dimana sebuah ide dialihkan dari satu orang sumber kepada yang lain baik secara verbal maupun non verbal. Dari beberapa pengertian tersebut, secara garis besar tujuan komunikasi adalah untuk merubah sikap, pendapat dan tingkah laku (kognisi, afeksi dan konasi) penerima pesan, sehingga komunikan melakukan seperti yang diharapkan oleh komunikator.

Aktivitas komunikasi juga tidak bisa dilepaskan dari penggunaan media komunikasi. Media komunikasi adalah alat atau perantara yang digunakan untuk mempermudah dan memperlancar proses penyampaian informasi atau pesan dari komunikator kepada komunikan, sehingga komunikan memahami makna pesan yang dimaksud sesuai dengan tujuan komunikator. Melalui media komunikasi yang tepat, tujuan komunikasi akan lebih mudah tercapai.

Komunikasi visual (komunikasi melalui penglihatan) adalah sebuah rangkaian proses penyampaian infromasi atau pesan kepada pihak lain dengan penggunaan media penggambaran yang hanya terbaca oleh indera penglihatan (media visual). Media visual mengkombinasikan seni, lambang, tipografi, gambar, desain grafis, ilustrasi, dan warna dalam penyampaiannya. Media visual berfungsi untuk menyalurkan pesan dari sumber ke penerima pesan. Pesan yang akan disampaikan dituangkan ke dalam simbol-simbol visual. Selain itu, fungsi media visual adalah untuk menarik perhatian, memperjelas sajian ide, menggambarkan atau menghiasi fakta yang mungkin akan cepat dilupakan jika tidak divisualkan.

\section{Dakwah Komunikasi Visual}

Dakwah komunikasi visual diartikan sebagai aktivitas yang dilakukan untuk menyampaikan informasi atau pesan yang mengajak untuk berbuat amar ma'ruf nahi mungkar sesuai dengan pedoman dalam al-Qur'an dan as-Sunnah, dengan memanfaatkan media komunikasi visual. Media komunikasi visual yang digunakan seperti iklan, poster, baliho, dan lain-lain.

Salah satu bentuk dakwah komunikasi visual yang sedang trend adalah melalui poster. Poster atau plakat adalah karya seni atau desain grafis yang memuat komposisi gambar dan huruf di atas kertas berukuran besar. Pengaplikasiannya dengan ditempel di dinding atau permukaan datar lainnya dengan sifat mencari perhatian mata sekuat mungkin. Karena itu poster biasanya dibuat dengan warna-warna kontras dan kuat.

Poster bisa menjadi sarana iklan, pendidikan, propaganda, sosialisasi dandekorasi. Selain itubisa pulaberupa salinan karya seni terkenal. Cat poster biasa juga disebut cat plakat karena memiliki sifat yang pekat, sifatnya datar cocok untuk menggambar dekoratif. (http://id.wikipedia.org/ wiki/Poster). Poster dapat dibuat di atas kertas, kain, batang kayu, seng dan sebagainya. Poster tidak saja penting untuk menyampaikan pesan atau kesan tertentu akan tetapi mampu pula untuk mempengaruhi dan memotivasi tingkah laku orang yang melihatnya. 
Poster merupakan salah satu mediapublikasiyangterdiriatastulisan, gambar ataupun kombinasi antar keduanya dengan tujuan memberikan informasi kepada khalayak ramai. Tujuan dibuatnya poster adalah untuk mengajak, membujuk atau menghimbau masyarakat untuk melakukan sesuatu seperti yang telah dituliskan dan digambarkan didalam poster tersebut. Tujuan poster tersebut harus tersampaikan kepada masyarakat banyak, oleh sebab itu poster biasanya dipasang ditempattempat umum yang dinilai strategis seperti sekolah, kantor, pasar, mall, lampu merah dan tempat-tempat keramaian lainnya (http://posterina. blogspot.com/2014/04/pengertianposter-serta-tujuannya.html).

Berdasarkan isi pesannya, poster dapat dibedakan menjadi berikut :

1. Poster Niaga, poster ini umumnya menawarkan produk suatu perusahaan.

2. Poster Kegiatan, poster ini menginformasi kegiatan kepada khalayak ramai.

3. Poster Pendidikan, poster ini ditujukan untuk hal-hal bertemakan pendidikan.

4. Poster Layanan Masyarakat, poster mengenai layanan umum pemerintah.

Sedangkan berdasarkan tujuannya, poster dibedakan menjadi :

1. Poster Propaganda, poster ini pengaruh sangat kuat terhadap masyarakat

2. Poster Kampanye, poster yang seringkali terlihat menjelang Pemilu.

3. Poster "Wanted" atau "Dicari", poster ini umumnya untuk mencari orang.

4. Poster "Cheesecake", poster ini dibuat untuk mencari perhatian masyarakat.

5. Poster Film, poster ini mempromosikan film agar dikenal masyarakat.

6. Poster Kartun, ini adalah poster publikasi dari komik-komik kartun.

7. Poster Afirmasi, poster ini tujuannya untuk memberikan motivasi.

8. Poster Riset, poster ini mempublikasikan riset dan penelitian.

9. Poster Kelas, poster ini bisa kita jumpai didalam kelas-kelas sekolah.

10. Poster Komersil, poster ini bertujuan untuk kepentingan komersil.

Salah satu bentuk poster yang bisa digunakan sebagai sarana dakwah adalah poster propaganda. Poster ini bisa dimanfaatkan sebagai ajakan untuk berbuat kebajikan dan mencegah kemungkaran melalui kalimat dan ilustrasi yang bernuansa islami, seperti kata-kata, kalimat ataupun gambar yang bersumber pada al-Qur'an dan hadits. Selain itu juga digunakan kata-kata mutiara atau kalimat hasil pemikiran dari para tokoh pemikir Islam.

Perkembangan poster bernuansa 
islami di Indonesia semakin pesat. Hal ini juga merupakan hasil dari perkembangan teknologi komunikasi dan informasi yang semakin maju. Kecerdasan masyarakat dalam mengkonsumsi media (baca=media massa) semakin tinggi. Dakwah tidak lagi hanya mengandalkan media audial saja, tetapi juga memanfaatkan media visual maupun audio visual. Media visual diyakini bisa membuat masyarakat penerima pesan dakwah lebih terstimulus, karena membutuhkan proses penafsiran makna yang lebih dalam, tidak semudah bila dibandingkan media audio visual yang sudah terpapar jelas.

Poster dakwah yang berisi kalimat-kalimat dan gambar yang bernuansa Islami dikembangkan untuk menjawab tantangan dakwah masa kini. Poster ini tidak dibuat asal-asalan tetapi harus setidaknya lima kriteria desain poster yang baik, yaitu adanya fokus tema, impact atau pengaruh, konsisten dengan detail, komposisi yang seimbang dan tipografi yang menarik. Desain poster ini dibuat sebaik mungkin untuk menarik minat pembaca yang menjadi penerima dakwah. Isi pesannyapun harus bersumber dari al-Qur'an dan hadits atau dari para tokoh pemikir Islam.

Muslim Designer Community (MDC) adalah salah satu kelompok komunitas designer muslim di Indonesia yang membuat poster-poster bernuansa islami. Komunitas ini terbentuk tahun 2013, berpusat di Gonilan, Surakarta dan beranggotakan lebih dari 8000 orang yang tersebar di Indonesia dan di luar negeri. Komunitas ini bertujuan unuk menyampaikan nilai-nilai dakwah yang tidak selamanya harus melalui ceramah, karena karya visual pun bisa berbicara dakwah. Lewat sajian poster-poster dengan muatan-muatan isi yang menarik dan kreatif namun tetap berpegang pada pegangan landasan Qur'an dan Sunnah. Hasil karya mereka sudah dipamerkan dalam beberapa event pameran, seperti pada acara penggalangan dana untuk Gaza, acara Car free day, pameran Book fair, dan lain sebagainya.

\section{Desain Komunikasi Visual}

Desain komunikasi visual merupakan salah satu bagian dari seni terap yang mempelajari perencanaan dan perancangan pelbagai bentuk informasi komunikasi visual. Perjalanan kreatifnya diawali dengan menemukan dan mengenali per-masalahan ko-munikasi visual, mencari data verbal dan visual, menyusun konsep kreatif yang berlandaskan karakteristik target sasaran, sampai dengan visualisasi final desain untuk mendukung tercapainya sebuah komunikasi verbal-visual yang fungsional, persuasif, artistik, estetis dan komunikatif (Tinarbuko, 2009 : 28). Artinya, menurut Sumbo Tinarbuko, desain komunikasi visual dapat dipahami sebagai salah satu upaya pemecahan masalah komunikasi atau komunikasi visual untuk menghasilkan suatu desain yang paling baru diantara desain yang baru (Tinarbuko, 1998 : 66). 
Sementara Widagdo (1993 : 31) menyatakan desain komunikasi visual dalam pengertian modern adalah desain yang dihasilkan dari rasionalitas, dilandasi pengetahuan, bersifat rasional dan pragmatis. Dunia desain komunikasi visual senantiasa dinamis, penuh gerak dan perubahan karena peradaban dan ilmu pengetahuan modern memungkinkan lahirnya industrialisasi. T. Sutanto (2005:15) menyatakan bahwa desain komunikasi visual senantiasa berhubungan dengan penampilan rupa yang dapat dicerap orang banyak dengan pikiran dan perasaan. Rupa yang mengandung pengertian atau makna, karakter atau suasana yang mampu dipahami oleh khalayak umum atau terbatas.

Desain komunikasi visual adalah ilmu yang mempelajari konsep komunikasi dan ungkapan daya kreatif, yang diaplikasikan dalam pelbagai media komunikasi visual dengan mengolah elemen desain grafis yang terdiri dari atas gambar (ilustrasi), huruf dan tipografi, warna, komposisi dan lay-out. Semua itu dilakukan untuk menyampaikan pesan secara visual, audio, dan/atau audio visual kepada target sasaran yang dituju.

Dalam dunia desain komunikasi visual, huruf dan tipografi adalah elemen penting yang sangat diperlukan untuk mendukung proses penyampaian pesan verbal dan visual. Tipografi dalam hal ini adalah seni memilih dan menata huruf untuk pelbagai kepentingan menyampaikan informasi berbentuk pesan sosial ataupun komersial. Tipografi da- lam konteks desain komunikasi visual mencakup pemilihan bentuk huruf, besar huruf, cara dan teknik penyusunan huruf menjadi kata atau kalimat sesuai dengan karakter pesan yang ingin disampaikan.

Ada beberapa faktor yang mempengaruhi mudah-tidaknya ketersampaian sebuah pesan verbal yang terkandung dalam karya desain komunikasi visual, diantaranya :

Pertama, latar belakang, yakni warna dasar dan tekstur kertas yang digunakan. Teks yang menjadi unsur utama dari sebuah pesan verbal akan terlihat jelas manakala keberadaan warna huruf dan latarnya cukup kontras.

Kedua, besar huruf yang digunakan. Ukuran standar teks adalah antara 6-10 point, tergantung luas ruangan yang tersedia dan banyak sedikitnya teks yang akan ditampilkan, juga menyesuaikan keluarga huruf yang ingin ditampilkan. Danton Sihombing (2001 : 28) menyatakan bahwa keluarga huruf terdiri atas pelbagai kembangan yang berakar dari struktur bentuk dasar (regular) sebuah alfabet dan setiap perubahan huruf masih memiliki kesinambungan bentuk. Perbedaan tampilan yang pokok dalam keluarga huruf dibagi menjadi tiga bentuk pengembangan : kelompok berat, terdiri dari light, regular dan bold; kelompok proporsi condesed, regular, dan extended; kelompok kemiringan yaitu italic.

Ketiga, spasi antar huruf, kata, mapun jarak antar baris kalimat.

Keempat, faktor-faktor subyektif 
seperti jarak baca maupun kualitas penerangan ketika membaca.

A.D. Pirous (1989) menyatakan bahwa desain komunikasi visual pada hakikatnya adalah suatu bahasa. Tugas utamanya adalah membawakan pesan dari seseorang, lembaga, atau kelompok masyarakat tertentu kepada orang lain. Sebagai bahasa, efektivitas penyampaian pesan tersebut menjadi pemikiran utama seorang desainer komunikasi visual.

Untuk itu seorang desainer haruslah: pertama, harus memahami seluk beluk bentuk pesan yang ingin disampaikan. Dengan memahami bentuk pesan yang ingin disampaikan, maka seorang desainer akan dengan mudah mengendalikan target sasaran untuk masuk kedalam jejaring komunikasi visual yang ditawarkan oleh sang komunikator (desainer komunikasi visual). Sebab sejatinya, karya desain komunikasi visual mengandung dua bentuk sekaligus, yaitu pesan verbal dan pesan visual. Tetapi dalam konteks desain komunikasi visual, bahasa visual mempunyai kesempatan untuk me-robek konsentrasi target sasaran, karena pesannya lebih cepat dan sangat mudah dipahami oleh target.

Kedua, mengetahui kemampuan menafsirkan serta kecenderungan kondisi fisik maupun psikis kelompok masyarakat yang menjadi sasaran.

Ketiga, harus dapat memilih jenis dan gaya bahasa yang serasi dengan pesan yang dibawakannya. Selain itu, jenis dan gaya bahasa juga harus tepat untuk dibicarakan secara efektif, jelas, mudah, dan mengesankan bagi si penerima pesan.

Desain komunikasi visual sebagai suatu sistem pemenuhan kebutuhan manusia di bidang informasi visual melalui simbol-simbol kasat mata, dewasa ini mengalami perkembangan yang sangat pesat. Hampir di segala sektor kegiatan manusia, simbolsimbol visual hadir dalam bentuk gambar, sistem tanda, sampai display di pelbagai pusat perbelanjaan.

Gambar merupakan salah satu wujud simbol atau gambar visual yang di dalamnya terkandung struktur rupa seperti garis, warna, dan komposisi. Gambar dikelompokkan kedalam kategori bahasa komunikasi nonverbal, dibedakan dengan bahasa verbal yang berwujud tulisan ataupun ucapan. Rancang grafis, yang kemudian berkembang menjadi desain komunikasi visual, memanfaatkan daya dukung gambar sebagai simbol visual pesan guna mengefektifkan komunikasi upaya mendayagunakan simbol-simbol visual berangkat dari pernyataan bahwa bahasa visual memiliki karakteristik yang sangat khas, bahkan istimewa, untuk menimbulkan efek tertentu pada pengamatnya. Hal demikian, pada bebrapa kasus sulit dicapai bila di-ungkapkan dengan bahasa verbal.

Ditambahkan Umar Hadi (1998), bahwa sebagai bahasa desain komunikasi visual adalah ungakapan ide dan pesan dari perancang kepada masyarakatyang ditujumelalui simbolsimbol berwujud gambar, warna, dan tulisan. Ia akan komunikatif apabila 
bahasa yang digunakan itu mudah dimengerti oleh khalayak sasarannya. Ia juga akan berkesan apabila dalam penyajiannya tersebut terdapat suatu keunikan sehingga ia tampil secara istimewa, mudah dibedakan dengan lainnya. Maka dalam berkomunikasi, diperlukan sejumlah pengetahuan yang memadai seputar target sasaran yang akan dituju dan bagaimana cara terbaik untuk berkomunikasi dengan mereka. Semakin baik dan lengkap pemahaman kita akan hal-hal tersebut, akan semakin mudah menciptakan bahasa visual yang komunikatif.

\section{Semiotika Visual}

Semiotika berasal dari kata Yunani : semeion, yang berarti tanda. Dalam pandangan Piliang (1998:262), penjelajahan semiotika sebagai metode kajian ke dalam pelbagai cabang keilmuan ini dimungkinkan karena ada kecenderungan untuk memandang pelbagai wacana sosial sebagai fenomena bahasa. Dengan kata lain, bahasa dijadikan model dalam pelbagai wacana sosial. Berdasarkan pandangan semiotika, bila seluruh praktik sosial dapat dianggap sebagai fenomena bahasa, maka semuanya dapat juga dipandang sebagai tanda.

Semiotika menurut Berger, memiliki dua tokoh, yakni Ferdinand de Saussure dan Charles Sander Pierce. Latar belakang keilmuan Saussure adalah linguistik, sedangkan Pierce filsafat. Saussure menyebut ilmu yang dikembangkannya semiologi (semiology). Semiologi menurut Saussure didasarkan pada anggapan bahwa selama perbuatan dan tingkah laku manusia membawa makna atau selama berfungsi sebagai tanda, dibelakangnya harus ada sistem pembedaan dan konvensi yang memungkinkan tanda itu. Dimana ada tanda, disana ada sistem.

Sedangkan Pierce menyebut ilmu yang dibangunnya semiotika (semiotics). Bagi Pierce yang ahli filsafat dan logika, penalaran manusia selalu dilakukan lewat tanda. Artinya manusia hanya dapat bernalar lewat tanda. Dalam pikirannya, logika sama dengan semiotika dan semiotika dapat diterapkan pada semua tanda.

Semiotika adalah ilmu yang mempelajari tanda (sign), berfungsinya tanda, dan produksi makna. Tanda adalah sesuatu yang bagi seseorang berarti sesuatu yang lain. Menurut Saussure, tanda adalah kesatuan dari dua bidang yang tidak dapat dipisahkan, seperti halnya selembar kertas. Artinya, sebuah tanda (berwujud kata atau gambar) mempunyai dua aspek yang ditangkap oleh indera kita yang disebut signifier, bidang penanda atau bentuk. Aspek lainnya disebut signified, bidang petanda atau konsep atau makana. Aspek kedua terkandung didalam aspek pertama. Jadi petanda merupakan konsep atau apa yang dipresentasikan oleh aspek pertama.

Penanda terletak pada tingkatan ungkapan (level of expression) dan mempunyai wujud atau merupakan bagian fisik seperti bunyi, huruf, kata, gambar, warna, objek, dan sebagainya. Sedangkan petanda terletak pada tingkatan isi atau gagasan (level of 
content) dari apa yang diungkapkan melalui tingkatan ungkapan. Tanda akan selalu mewakili sesuatu hal yang lain. Ini disebut referent. Misalnya lampu merah mengacu pada jalan berhenti. Wajah cerah mengacu pada kebahagiaan. Apabila hubungan antara tanda dan yang diacu terjadi, maka dalam benak orang yang melihat atau mendengar akan timbul pengertian (Eco, 1979:59).

Pierce menyatakan bahwa tanda dalam hubungannya dengan acuannya dibedakan dengan ikon, indeks dan simbol. Ikon adalah tanda yang antara tanda dengan acuannya ada hubungan kemiripan atau biasa disebut dengan metafora. Bila ada hubungan kedekatan eksistensi, disebut indeks. Tanda seperti ini disebut metonimi. Simbol adalah tanda yang diakui keberadaannya berdasarkan hukum konvensi. Ikon, indeks dan simbol merupakan perangkat hubungan antara dasar (bentuk), objek (referent) dan konsep (interpretant atau reference).

Semiotika visual (visual semiotics) pada dasarnya merupakan salah sebuah bidang studi semiotika yang secara khusus menaruh minat pada penyelidikan terhadap segala jenis makna yang disampaikan melalui sarana indera lihatan (visual senses) (Budiman, 2011:9).

Sementara Roland Barthes, seperti yang dikutip oleh Tinarbuko (2009:15), menyatakan bahwa faktor penting dalam konotasi adalah penanda dalam tatanan pertama. Penanda tatanan pertama merupakan tanda konotasi. Jika teori itu dikaitkan dengan desain komunikasi visual (DKV), maka setiap pesan DKV merupakan pertemuan antara signifier (lapisan ungkapan) dan signified (lapisan makna). Melalui unsur verbal dan visual (nonverbal), diperoleh dua tingaktan makna, yaitu makna denotatif yang didapat pada semiosis tingkat pertama dan makna konotatif yang didapat pada semiosis tingkat berikutnya.

Terkait dengan itu, pembahasan karya desain komunikasi visual dengan kajian semiotika visual dalam tulisan ini akan menggunakan (i) teori Pierce untuk melihat ikon, indeks dan simbol, (ii) teori Saussure untuk melihat makna konotatif dan denotatif, (iii) teori Barthes untuk melihat kode (kode hermeneutik, kode simbolik, kode narasi, kode semantik, dan kode kebudayaan).

Berikut dua gambar contoh poster hasil karya Muslim Designer Community (MDC) : 


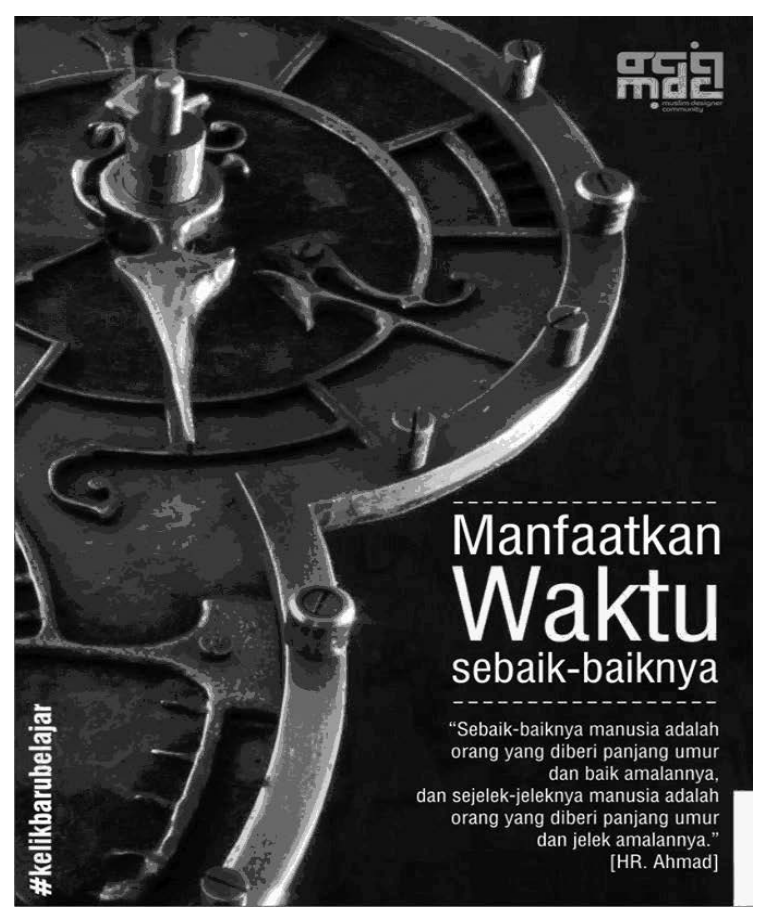

Gambar 1 :

\section{Analisis Semiotika komunikasi visual Gambar 1 :}

\section{Tanda Verbal :}

Headline : Manfaatkan Waktu Sebaik-baiknya

Teks : "Sebaik-baiknya manusia adalah orang yang diberi umur panjang dan baik amalannya, dan sejelek-jelek manusia adalah orang yang diberi panjang umur dan jelek amalannya." (HR. Ahmad).

\section{Tanda Visual :}

Ikon sebuah jam dinding model klasik yang terbuat dari besi tembaga. Jam dinding yang terlihat sangat kokoh dan kuat.

Pada poster gambar 1, terlihat bahwa dasar poster menggunakan warna hitam dengan tanda visual jam dinding berbahan besi tembaga. Warna hitam menunjukkan ketegasan, sementara besi tembaga menunjukkan kekuatan dan kekokohan. Berdasarkan tipografinya, tulisan yang digunakan menggunakan keluarga huruf Sans Sherif dengan warna putih dan kuning, sehingga terlihat kontras dengan warna dasar poster. Ukuran huruf yang digunakan berbedabeda (analisis berdasarkan ukuran dalam format kertas, bukan ukuran sebenarnya). Pada headline, kata "Manfaatkan" menggunakan ukuran font 14, sedangkan pada kata "Waktu" menggunakan ukuran 28 dan berwarna kuning, sementara kata "sebaikbaiknya" menggunakan ukuran 12 . Padakalimatteksmenggunakanukuran 11. Hal ini untuk menunjukkan bahwa kata "waktu" sengaja ditampilkan sebagai pusat perhatian, warna kuning menunjukkan antusiasme dan energi. Bahwa waktu memegang peran yang sangat penting dalam hidup kita, tidak bisa diputar kembali sehingga harus dimanfaatkan sebaik-baiknya dengan antusiame yang tinggi.

Ikon jam dinding yang terbuat dari besi tembaga yang kokoh semakin mempertegas bahwa sang waktu adalah sesuatu yang tidak bisa dihancurkan, akan terus berputar maju dan tidak bisa dimundurkan atau dihentikan. Dalam sehari ada waktu 24 jam dan 365 hari dalam setahun. Tidak ada penambahan dan pengurangan waktu.

Pada level teks, dimensi narasi menunjukkan bahwa manusia harus menghargai waktu dengan menggunakannya untuk berbuat kebajikan. Sesuai dengan sabda Rasulullah SAW, bahwa sebaik-baik manusia adalah manusia yang diberi 
panjang umur dan baik amalnya dan sejelek-jelek manusia adalah yang diberi panjang umur dan jelek amalnya. Waktu menunjukkan bahwa manusia diberikan kesempatan untuk mengisi waktunya dengan berbuat amal kebajikan, sehingga menjadi manusia yang baik di mata Allah. Sebaliknya manusia yang tidak memanfaatkan waktunya dengan berbuat baik akan menjadi manusia yang hina di mata Allah SWT.

Dari Abu Bakar RA, "Wahai Nabi Saw, siapakah manusia yang paling baik?". Beliau Bersabda, "Orang yang panjang umur dan baik amalnya". Ia bertanya lagi, "siapakah manusia yang jelek?”, Nabi menjawab, “Orang yang panjang umur lagi buruk amal nya". (HR Ahmad dan At-Tirmidzi).

Dari Abu hurairah RA, berkata Nabi Saw, "Maukah kalian aku kabarkan siapa yang terbaik dari kalian?". Sahabat menjawab, "Iya". Nabi Saw berkata, "Sebaik-baik kalian adalah yang paling panjang umurnya dan paling baik amalnya". (HR Ahmad).

Barang siapa yang memohon dipanjangkan umurnya agar dapat melakukan amal sholeh yang dapat mendekatkan dirinya kepada Allah SWT dan dia bersemangat dalam beramal, maka orang tersebut adalah orang-orang yang benar (shodiqin). Tetapi jika dengan keinginannya tersebut dia bermalas-malasan dalam beramal, maka jelas dia adalah seorang pendusta (kadzibin).

Dunia adalah tempat untuk beramal (Daarul 'amal) sedangkan akhirat adalah tempat menuai ganjaran (Daarul jaza'). Sebaik-baiknya manusia adalah umur amalnya lebih panjang dari umur biologisnya. Orang yang pendek umurnya namun setelah kematiannya kebaikannya masih selalu diceritakan orang dan amalnya masih ditiru orang, itulah orang beruntung dan sholeh. Namun sebaliknya umurnya panjang, tapi tidak ada kebaikan yang dapat ditiru dan dikenang orang, sia-sialah hidupnya dan merugilah ia.

Analisis semiotika visual dari gambar 1 menunjukkan bahwa ada keterkaitan antara tanda verbal dan tanda visual. Bahwa manusia harus bisa memanfaatkan waktu dengan sebaik-baiknya dengan berbuat amal kebajikan, karena sang waktu tidak bisa diputar kembali.

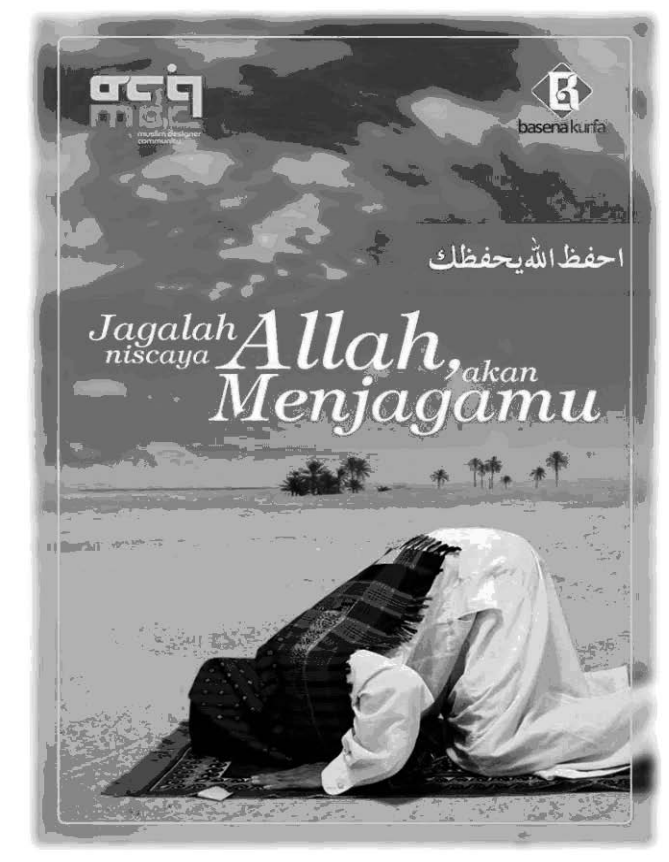

Gambar 2 : 


\section{Analisis Semiotika komunikasi visual Gambar 2 :}

\section{Tanda Verbal :}

Headline : Jagalah Allah, niscaya Allah akan menjagamu

Teks : Ihfadzillaha yahfadzka (nukilan hadits dalam tulisan bahasa Arab)

\section{Tanda Visual :}

Ikon laki-laki yang mengenakan baju gamis berwarna putih dan bersurban kotak-kotak biru sedang bersujud beralas sajadah di sekeliling gurun pasir. Suasana siang hari dengan background pohon palm di kejauhan dan langit berwarna biru cerah.

\section{Analisis :}

Berdasarkan tipografi yang digunakan, pada level headline dan teks warna tulisan yang digunakan putih dengan latar belakang warna biru cerah, sehingga terlihat kontras antara tulisan dan warna dasar dan ini memudahkan fokus pembaca. Huruf yang digunakan jenis Egyptian dengan ukuran (analisis berdasarkan ukuran kertas bukan ukuran sebenarnya), kata "Jagalah" ukuran 12, "niscaya" dan "maka" dengan font 11, kata "menjagamu" dengan font 18 dan kata "Allah" dengan ukuran font 28. Kata "Allah" hanya ditulis satu kali untuk dua kali pembacaan, hal ini untuk memberikan penekanan bahwa Allah SWT memang hanya satu. Penggunaan teks dengan bahasa Arab digunakan untuk meyakinkan pembaca bahwa kalimat tersebut merupakan nukilan yang bersumber dari Al-Qur'an ataupun hadits. Selain itu juga untuk mendukung tanda visual berupa gurun pasir yang memang identik dengan negara Arab.

Ikon orang yang sedang bersujud menunjukkan ketundukan dan kepasrahannya kepada Allah Yang Maha Kuasa. Posisi bersujud adalah posisi dimana kepala manusia menempel di alas sujud, tidak bisa menengok ke kiri, ke kanan, keatas atau ke bawah, benar-benar berkonsentrasi penuh pada alas sujud. Hal ini menunjukkan bahwa ketika bersujud, apapun yang terjadi diserahkan pada Yang Maha Kuasa, bahwa Allah SWT akan menjaga orang-orang yang berpasrah kepada-Nya. Baju putih menandakan kesucian. Ketika menghadap Allah SWT harus selalu dalam keadaan suci dan bersih.

Indeks yang ditampilkan adalah gurun pasir dan cuaca cerah berwarna biru langit. Gurun pasir adalah daerah dimana frekuensi hujan sangat jarang terjadi, lebih banyak didominasi cuaca panas. Warna biru melambangkan ketenangan. Hal ini menunjukkan bahwa meskipun cuaca panas, ketika melaksanakan ibadah akan terasa tenang. Pohon Palm adalah pohon yang tahan terhadap cuaca apapun, meskipun tidak harus disiram air setiap hari, tapi mampu bertahan di segala musim. Muslim seharusnya bisa bertahan dari segala macam godaan dan ujian.

Di dalam hadis ini Rasulllah SAW mewasiatkan beberapa untai kalimat kepada Ibnu 'Abbas, 'Jagalah Allah, niscaya Dia akan menjagamu'.

Melalui putra pamannya itu, 
Nabi mengajarkan kita semua, bila kita menjaga Allah dengan sebaikbaiknya, Allah SWT pasti akan menjaga kita dengan penjagaan yang melebihi upaya kita. Menurut para ulama, menjaga Allah artinya menjaga batasan-batasan-Nya, hakhak, perintah-perintah, serta laranganlarangan-Nya. Bentuk aplikasinya adalah dengan berkomitmen untuk menjalankan perintah Allah SWT, menjauhi larangan-Nya, dan tidak melampaui batasan yang dilarang oleh-Nya. Jika semua itu dikerjakan, maka ia termasuk orang yang menjaga Allah SWT sebaik-baiknya. Pemilik kriteria inilah yang disanjung oleh Allah SWT.

Rasulullah bersabda, 'Hak Allah atas hamba-Nya adalah beribadah hanya kepada-Nya dan tidak menyekutukan-Nya." (HR. Bukhari: 2856 dan Muslim: 48). Juga termasuk upaya menjaga Allah adalah menjaga shalat agar senantiasa tepat pada waktunya. Demikian juga termasuk dalam upaya menjaga Allah adalah menjaga lisan dari segala bentuk kedustaan, perkataan kotor, adu domba, menggunjing, dan menjaga kemaluan serta menundukkan pandangan.

Analisis tanda visual dan verbal saling mendukung, bahwa ketika kita menjaga hak-hak Allah SWT, dengan melaksanakan perintahnya, seperti menjalankan ibadah sholat dalam kondisi apapun, maka Allah SWT senantiasa akan menjaga kita.

\section{PENUTUP}

Dakwah bisa dilakukan oleh siapa saja, kapan saja, dimana saja dan melalui media apa saja. Seiring perkembangan zaman dan kecanggihan teknologi informasi dan komunikasi, media dakwahpun harus menyesuaikan dengan situasi dan kondisi zaman. Media dakwah komunikasi visual menjadi salah satu pilihan. Media visual akan lebih mudah dicerna atau dipahami. Kecenderungan orang untuk memaknai pesan melalui gambar lebih mudah daripada media lain. Salah satu bentuk dakwah komunikasi visual adalah melalui poster-poster yang bernafaskan Islam, berisi kalimatkalimat motivasi yang bersumber dari al-Qur'an dan as-Sunnah, yang mengajak manusia untuk berbuat amar ma'ruf nahi munkar. Poster ini bisa ditempelkan di tempat-tempat yang terdekat dengan tempat tinggal kita agar bisa dilihat setiap saat. Dengan melihat poster bernuansa Islam, diharapkan akan menjadi motivasi bagi umat Islam agar selalu ingat kepada Allah, melaksanakan perintahNya dan menjauhi larangan-Nya.

\section{DAFTAR RUJUKAN}

Azis, Moh. Ali, 2004. Ilmu Dakwah. Jakarta : Prenada Media

karta : Prenada Media

Budiman, Kris. 2011. Semiotika

Visual. Yogyakarta : Jalasutra

Eco, Umberto. 1979. A Theory of Semiotics. Bloomington : Indiana University Press 
Effendy, Onong Uchyana. 1993. Dinamika Komunikasi, Bandung : Remaja Rosdakarya

Ilaihi, Wahyu. 2006. Manajemen Dakwah, Jakarta : Kencana

-------, 2010. Komunikasi Dakwah. Bandung : Remaja Rosda Karya

Munawwir, Ahmad Warson. 1997. Kamus Al-Munawwir ArabIndonesia Terlengkap, Edisi Ke-2, Surabaya : Pustaka Progresif.

Piliang, Yasraf Amir. 1998. Sebuah Dunia yang Dilipat, Realitas Kebudayaan menjelang Millenium Ketiga dan Matinya Posmodernisme. Bandung : Mizan

Riswandi, 2009. Ilmu Komunikasi. Yogyakarta : Graha Ilmu

Sihombing, Danton. 2001. Tipografi dalam Desain Grafis. Jakarta : Gramedia Pustaka Utama

Shaleh, Rosyad. 1977. Manajemen Dakwah Islam. Jakarta : Bulan Bintang

Syukir, Asmuni. 1983. Dasardasar Strategi Dakwah Islam. Surabaya : Al-Ikhlas

Tinarbuko, Sumbo. 2009. Semiotika Komunikasi Visual. Yogyakarta : Jalasutra

Hadi, Umar. 1998. "Memahami Desain Grafis". Katalog pameran Desain Grafis. LPK Visi Yogyakarta

Sutanto, T. 2005. "Sekitar Dunia Desain Grafis/Komunikasi Visual". Pura-pura Jurnal DKV ITB Bandung 2/Juli
Widagdo. 1993. "Desain : Teori dan Praktik. Seni Jurnal Pengetahuan dan Penciptaan Seni”. BP ISI Yogyakarta III/03

Tinarbuko, Sumbo.1998. "Memaknai Tanda, Kode, dan Makna Iklan Layanan Masyarakat". Tesis. Bandung : ITB Bandung

http://posterina.blogspot. com/2014/04/pengertian-poster-sertatujuannya.html.

http://id.wikipedia.org/wiki/

\section{Poster}

